\title{
MARKETING COMPETENCE OF DIRECTORS IN COMPETITIVENESS PROVISION OF VOCATIONAL TRAINING INSTITUTIONS AT THE EDUCATIONAL SERVICES MARKET
}

\author{
Olena Zagika, \\ $\mathrm{PhD}$ in Pedagogy, director of higher professional school № 25, Khmelnytsky, \\ http://orcid.org/0000-0001-8004-9338 \\ e-mail: zagika.olena@gmail.com
}

\begin{abstract}
Vocational training institution is considered to be an open social and pedagogical system, a subject of market relations, which operates simultaneously at the market of educational services and the labor market, ensuring the identification and satisfaction of educational needs of consumers through the offer of educational services. It has been proved that the development of human capital achieves the best results in the favorable environment for economic growth, where decisions on the training of workers and specialists are made on the basis of social partnership at the local and regional levels. In this context, (the main ideas of implementation of monitoring mechanisms, better regulation and provision with vocational education quality, staff training in accordance with the current and future needs of the labor market in conditions of decentralization, enhanced cooperation between public administrations and employers, and the establishment of social partnership) are analyzed. The search for modern approaches to planning the activities of the educational institution, the quality improvement of educational services, effective training of specialists, in particular, marketing planning (main objective of which is to increase the competitiveness of institutions and their educational services) are of particular relevance.

The author considers the marketing approach to managing the competitiveness of the educational institution on the basis of studying the trends of the economy and the labor market, the needs and interests of consumers of educational services; he determines the criteria of competitiveness of the educational institution. It is determined that the creation of a scientific basis for the development of marketing competence of the directors is necessary for the adaptation provision of the educational proposal to the needs of the labor market, the introduction of modern information and analytical tools for the effective planning and management of vocational training institutions. The conceptual foundations of competence, systemic, adaptive, informational approaches are analyzed, which are the methodological substratum for determining the content and formation of the system of development of marketing competence of directors, search of ways to increase the efficiency of making managerial decisions on the activities and development of institutions of vocational education and training.
\end{abstract}

Keywords: vocational education and training, competitiveness of educational institution, marketing management, marketing competence of the director, market of educational services.

Introduction. Modern processes of the development of the post-industrial society, the introduction of ideas of sustainable development and decentralization of management in Ukraine, dynamic social and economic transformations lead to changes in the functions of vocational education (vocational education and training) (hereinafter: VET) (Svistun et al., 2012). In accordance with the world educational trends, the transformation of the system of vocational education takes place, new development strategies are introduced, which take into account the need for its (VET) adaptation to democratic and market transformations in society, Ukraine's accession to the European and world informational and educational space. 
The experience of the economically developed countries of the world shows that the development of human capital achieves the best results in the favorable environment for economic growth, and where decisions on the training of workers and specialists are taken on the basis of social partnership, in close cooperation between the Government, employers and representatives of hired employees, starting with local and regional levels (Palkevich, 2014).

The current stage of the development of VET in Ukraine is characterized by intensive searches of something new in the theory and practice of the activity of the vocational (education and training) institutions (hereinafter: VET institutions) on the basis of developing a strategy for long-term development in the conditions of the interaction between the labor market and educational market services. The establishment of vocational education as a subject of market relations, operates simultaneously at two markets: the market of educational services and the labor market, and this is the feature of its activity (Svistun et al., 2016, p. 9). The task of the institution of education in conditions of the market economy is to identify and satisfy the educational needs of consumers through the proposed educational services (Ryabova, 2010). The search for modern approaches to the planning of the activity of educational institution, the improved provision of educational services quality, effective training of specialists are of special actuality in the conditions of competition at the market of educational services, expansion of the autonomy of the activity of the VET institutions and the responsibility of directors for the results of training the working personnel, staffing, educational and methodological and economic support of the educational process One of the types of planning of economic activity of VET institutions is the planning of marketing activity, the main purpose of which is to increase competitiveness of institutions and their educational services (Anishchenko et al., 2008).

In that context, there exists an acute problem of the ability of directors of VET institutions to make effective management decisions on the formation of an educational proposal and interaction with social partners on the basis of market analysis of labor markets and educational services. In this regard, in order to introduce the significant changes in the existing system of formation of professional competence of directors of VET institutions, in particular the development of their marketing competence, it is necessary to provide this process with information-analytical character that will result in the introduction of monitoring, better regulation and provision of vocational education quality, training in accordance with the current and future needs of the labor market.
Materials and methods. The scientific and theoretical basis for the study of the mentioned problem is made up of the works of Ukrainian and foreign researchers whose subject of scientific research is the following: methodological and theoretical foundations of the development of vocational education in modern social and economic conditions (M. Artyushina, S. Artyukh, S. Batishev, M. Berulava, N. Bryukhanova, S. Goncharenko, R. Gurevich, G. Yelnikova, O. Kovalenko, P. Luzan, N. Nichkalo, V. Oliynyk, V. Orlov, V. Radkevich, G. Romanova, A. Shcherbak and others); modern world approaches in the field of marketing, marketing management and peculiarities of marketing activities in Ukraine (L. Balabanova, J. Blait, N. Butetenko, S. Harkavenko, D. Gobber, F. Kotler, T. Lukianets, Y. Petrunja, A. Starostina and others); theoretical and methodological principles of educational marketing and marketing activity in the system of higher education (V. Sargent, V. Poltorak, L. Karamushka, E. Golubkov); in the system of vocational education (Y. Palkevich, P. Pomaran, N. Protsenko, T. Rukavichka, Z. Riabov, V. Svistun, G. Chernobuk, etc.).

The aim of the paper is to analyze the approaches to increasing the competitiveness of vocational training institutions at the market of educational services by developing the marketing competence of directors of VET institutions.

Results and discussions. Development of the labor market and associated with it market of educational services in vocational education, contradictions and the crisis of the educational system determine the socioeconomic, psychological-pedagogical and scientifictechnical criteria in the management of educational and productive activity of the teaching staff of VET institutions. The new management development paradigm of the VET institutions contains the process of forming an organization, streamlining the subjectsubject relations through coordination, alignment of positions and actions of managers and pedagogical workers (as the main subject of management), and the product of management activity is a diversely wellgrounded strategy for the development of the educational institution (Solovy, Genyk and Solovyi, 2014, p. 19-20).

VET institution is an open social and pedagogical system with productive and economic functions, and as any complex object, that is the set of interconnected elements that exist in a dialectical relationship, have the same purpose, and which are marked by a certain degree ordering. The interrelation of VET institutions with the environment,(the factors of which cause changes in internal structural elements), testifies about their openness. Therefore, we consider it expedient to analyze the system of development of marketing 
competence of directors, taking into account the methodological fundamentals of the system approach (V. Bespalko, Y. Konarzhevsky, N. Kuzmina, etc.), which allows to take into account the dialectical relationship between the labor market and the market of educational services, ensure consistency of decision making at all levels of management of educational institutions.

The internal factors of competitiveness of VET institutions are, in particular, the marketing competence of directors (headmaster, deputy director of educational and practical work, senior masters), the relevance of the educational proposal to the needs of the labor market, and high-quality information provision of the activity of the educational institution.

Conceptual principles for the development of marketing competence of directors of VET institutions, the main ideas for introducing monitoring mechanisms, better regulation and quality assurance of vocational education, staff training in accordance with current and promising needs of the labor market in conditions of decentralization, strengthening of cooperation between public administrations and employers, social partnership building are highlighted in the Concept of Vocational Education Reform in Ukraine "Modern Vocational Education" (2018), in the U-LEAD Project Reports (2018).

The main principles of the concept of competence approach are reflected in the writings of scientists: V. Baidenko, V. Kremen, V. Lugovoi and others. In particular, the concept of a competent approach in vocational education, according to V. Radkevich, aims at forming a personality of the professional with the positive outlook, valuable orientations, the ability to adapt quickly to traditional or new and unpredictable life and professional situations (Radkevich, 2012, p. 11). Scientific researches of G. Yelnikova, N. Nichkalo, V. Radkevich, V. Svistun, and others are devoted to the improvement of the management of VET institutions with regard to the trends in the development of the labor market. The problems of analyzing and implementing a competent approach are supported by modern scholars and practitioners, among which are O. Lokshina, O. Savchenko O. Ovcharuk et al. Significant studies were carried out thanks to the cooperation of the Ministry of Education and Science of Ukraine, the National Academy of Pedagogical Sciences of Ukraine and international organizations of the country on educational policy, due to which the main principles of the competence approach were highlighted.

Competence is defined by researchers as an integrated characteristic of personality quality, an efficient unit, formed through experience, knowledge, skills, attitudes, behavioral reactions. Competence is based on a combination of mutually relevant cognitive relationships and practical skills, values, emotions, behavioral components, knowledge and skills, everything that can be mobilized for the active action.

Analyzing the contents of marketing competence of directors in terms of competence approach, we conclude that the marketing competence of the director - is the ability to integrate knowledge and skills and use them effectively in conditions of the marketing environment that can be considered as a component of professional competence in modern conditions. The researcher I. Kushnir (2013, p. 100) interprets the marketing competence of directors as "professionalism, which includes knowledge of marketing theory; the ability to form and implement a marketing strategy, carry out effective communicative acts that promote the competitiveness of an educational institution, expressed in the ability to formulate the needs of the humanitarian order, satisfying the interests of the state, society and personality".

In the author's opinion, the adaptation of the directors of educational institutions is an important and significant component of professional competence in the conditions of a dynamic changing environment, the development of techniques and technologies, demands and requirements of employers, and competence is a complex synthesis of cognitive, subject-practical, and personal experience. Thus, the marketing competence of the director as a factor in the competitiveness of the institution of education is "a consequence of self-organization and generalization of action-related and personal experience" (Anishchenko et al., 2008, p. 26). In this context, it is reasonable and justified to apply the methodological principles of the adaptive approach (T. Borova, G. Yelnikova, G. Polyakova, Z. Ryabova, P. Tretyakov, etc.), which ensures the priority of development of the subjects of activity and is carried out through the processes of self-organization. The principle of selforganization involves the interaction of the subjects of the labor market, educational services, social partners, the public in the process of specifying the objectives, plans, training programs, strategies for the development of educational institutions. These processes are aimed at achieving a common goal, the main elements of which are the requirements of the environment (people, organizations, etc.) and the real situation consideration. That is, with the help of the adaptive approach, there is a mutual agreement between the subjects of labor markets and educational services.

Scientists V. Svistun, L. Petrenko, N. Protsenko (2016) paid attention to the study of marketing competence of directors, in terms of the informational approach, as a combination of methods of scientific 
knowledge, principles, conditions "associated with the implementation of professional and research tasks that are provided by computer science and implemented in the process of information and analysis activity of the specialist. Marketing competence is a methodological basis for the management of vocational education marketing". The actuality of the use of the informational approach is conditioned with the introduction of market mechanisms for the development of vocational education and training, the improvement of the quality of skilled workers training and provision with the needs of the labor market (Ryabova, 2010, p. 15-19).

Thus, the effective activity of VET institutions in conditions of the market economy forseees the introduction of marketing management of VET institutions based on a complex system approach to solving the tasks of the educational institution, its competitiveness. Therefore, the system of development of marketing competence of directors should take into account the methodological principles of systemic, competent, informational and adaptive approaches, which will become the modern scientific basis of marketing management for the formation of a relevant educational proposal and qualitative information provision of the process of professional training of specialists in accordance with the requirements of the labor market.

The marketing management of the VET institutions covers all aspects of its activities, from the study of trends in the development of the economy and the labor market, the needs and interests of consumers of educational services, the organization of vocational guidance work - to the assurance of an exact cycle of training of working personnel, their employment and the creation of conditions for further professional and career growth of the population of the region (Svistun et al., 2012, p. 8-14). According to V. Radkevich, marketing approach to management activity in vocational training institutions is an important basis for the management of the quality of vocational education, unification of the efforts of administrative and teaching staff of VET institutions, which will contribute to satisfying the needs of the population, business entities and the state in educational services of a different nature. For this purpose, marketing services are being created in vocational training institutions (Radkevich, 2016, p. 17).

The basis of the methodology of marketing management of the competitiveness of the institution of education at the market of educational services by scientists and researchers is the idea about the integrity of the mechanisms of forecasting and planning of marketing research in VET institutions (Garkusha, Tsukova and Goroshanska, 2011; Lepa and Debela,
2007; Palkevich, 2014), the basis of which is a marketing program, a certain cycle of actions based on the analysis of the internal (resources) and the external environment of the educational institution, proposed by Z. Ryabova (2012).

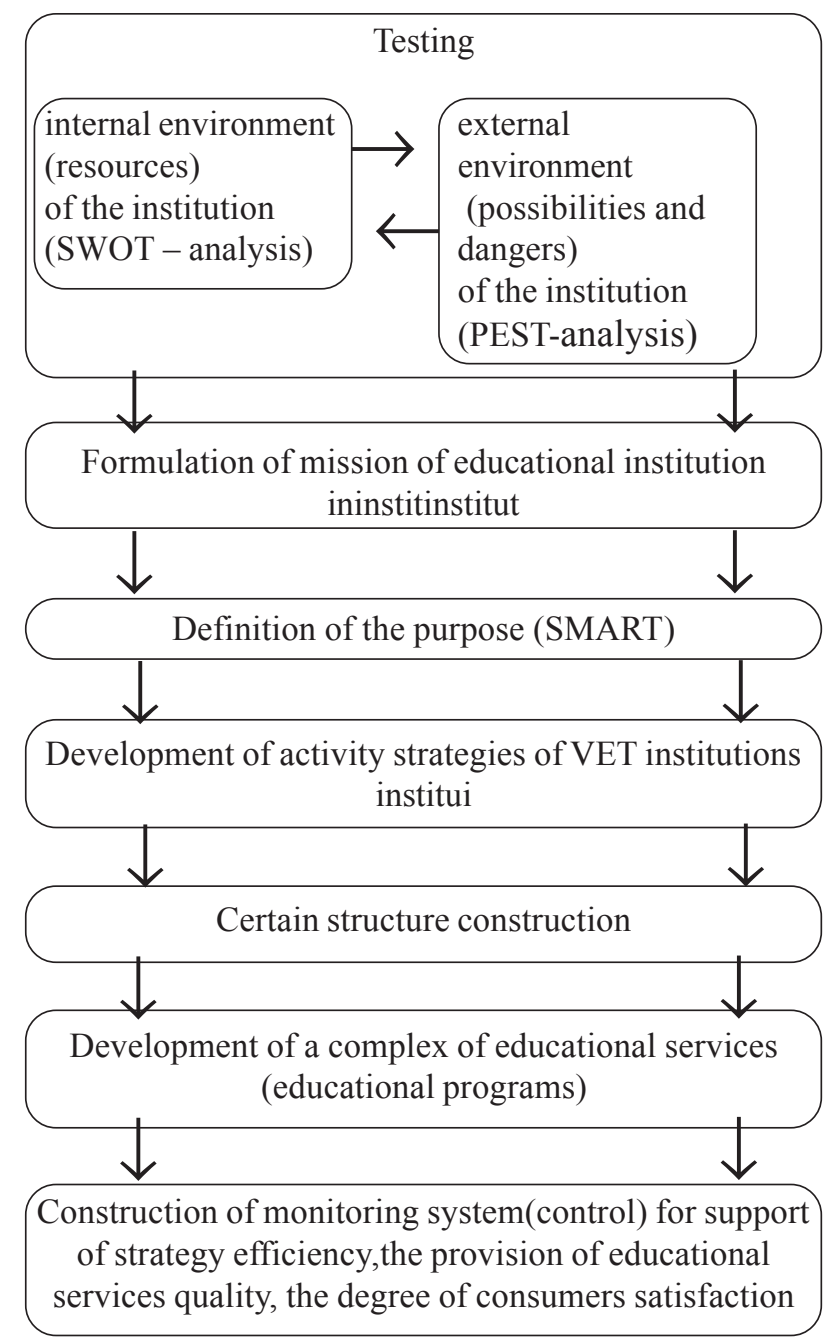
Fig. 1. Marketing program for studying the
environment of educational institution.

The methodology is based on the targeted forecasting of the most probable condition, trends and peculiarities of the development of VET institutions in the perspective period on the basis of detection and proper assessment of stable connections and relationships between the criteria which characterize the external conditions of the functioning of VET institutions and the internal competitiveness potential of educational institutions. The results of forecasting are the scientific basis for the adoption and practical implementation of managerial decisions and the regulation of certain stages of planning. One of these stages is the development and implementation of the competitiveness criteria of VET institutions 
(Palkevich, 2014). In particular, the criteria that determine the internal potential of the educational institution may be: the level of updating the material and technical base during the last three years, the percentage of employed graduates on the given profession, the availability and number of new educational services during the last three years, the payback period of new educational services, the level of personnel provision of the institution, number of sources of funding, systematic marketing research. The criteria that characterize the external conditions of the operation of the VET institutions are: the market segment, at which the service is oriented, the number of enterprises in the region for which workers are trained, the availability of vacancies at these enterprises, the prospects for the development of the corresponding industry, the effectiveness of social partnership, interaction with state regulatory bodies, etc.

The approximation of the labor market and the market of educational services, forecasting and planning of management of their development is a complex, continuous, multifactorial, interregional and inter-sectoral process. Despite the complex financial and economic conditions for the functioning of the system of VET institutions and the lack of workability of mechanisms for coordinating the labor market and correcting its fluctuations, the most important task is the close cooperation of these two markets in developing common methodological approaches to the creation of operational, tactical and strategic plans for the preparation and employment of graduates (Palkevich, 2014).

In this context, the present puts forward special requirements to the directors of the VET institutions who have to expand their professional competence and functions significantly, for satisfying the managerial needs in the system of vocational education and training.

Conclusions. Thus, orientation at the demands of the labor market, social partners, community demands, search and introduction of something new encourage scholars and practitioners to find modern approaches to management, create a scientific basis for educational management, form the director of the new generation, for which marketing competence becomes an important component of professional competence.

The modern director must have a thorough knowledge of the methods and techniques of management based on systematic marketing research. He must have progressive views, deep analytical and perspective thinking, understand that further improvement of the system of vocational education requires the establishment of mechanisms of cooperation between VET institutions and social partners, the formation (on this basis) of the educational proposal, the adaptation of educational content to the needs of employers, better quality education, etc. This will ensure the training of highly skilled workers, adapted to the current economic conditions and requirements of the labor market, and will help to increase the level of competitiveness of the educational institution at the market of educational services.

\section{List of references}

Гаркуша, Н.М., Цукова О.В., Горошанська, О.О., 2011. Моделі й методи прийняття рімень в аналізі та аудиті. Київ: Знання. (Вища освіта ХХІ століття).

Свистун, В.І., Айстраханова, Д.Д., Сльникова, Г.В та ін., 2012. Децентралізація управління професійно-технічною освітою: монографія. Київ: Педагогічна думка.

Кушнір, I. І., 2013.Зміст маркетингової компетентності керівників вищих навчальних закладів I-II рівнів акредитації. Науковий вісник Ужгородського університету. Серія: Педагогіка. Соиіальна робота, 27, с. 99-102.

Лєпа, Є.К., Дебела, І.М., 2007. Прогнозування сочіально-економічних прочесів: навч. посіб. для студ. економ. спец. Херсон: ВАТ "Херсонська міська друкарня".

Свистун, В.І., Помаран, П.І., Палькевич, Ю.С., Чернобук, Г.Г. та ін., 2015. Маркетингове управління професійно-технічним навчальним закладом в умовах ринкової економіки: метод. посіб. /за ред.В.О.Радкевич, В.І.Свистун. Ромни: Роменське ВПУ.

Анішенко, В.М., Закатнов, Д.О., Здірук, С.І. та ін., 2008. Напрями реформування професійно-технічної освіти в умовах європейської інтеграції (досвід, аналіз, прогнози): колективна монографія. Київ: ІПТО НАПН України.

Палькевич, Ю.С., 2014. Управління конкурентоспроможністю освітніх послуг професійно-технічних навчальних закладів: методичні підходи до прогнозування та планування. Науковий вісник Інституту професійно-технічної освіти НАПН Украӥни. Професійна педагогіка, 1(8), с. 28-32.

Палькевич, Ю.С., 2014. Управління розвитком професійно-технічної освіти: економічний аспект. В: Ринкові економічні механізми сталого розвитку: інноваційне та фінансове забезпечення: матеріали міжнародної науково-практичної конференції "9-10 травня 2014 р. НГУ, Дніпропетровськ"), с. 197-198.

Радкевич, В. О., 2012. Компетентнісний підхід до забезпечення якості професійної освіти і навчання. В: Науково-методичне забезпечення професійної освіти $і$ навчання: матеріали Всеукр. (звіт.) наук.-практ. конф. (23 березня 2012 р., м. Київ ), Київ: Ін-т проф.-техн. освіти НАПН України. Вип. 1, с. 9-15.

Радкевич, В. О., 2016. Теоретичні та методичні засади розвитку професійної освіти і навчання: результати, проблеми, перспективи. Науковий вісник Інституту професійно-технічної освіти НАПН України. Професійна педагогіка, 11, с. 5-23. 
Свистун, В.І., ред., Петренко, Л.М., Проценко, Н.Д., 2016. Розвиток маркетингової компетентності керівників ПТНЗ: наук.-метод. посіб. Київ: ІПТО НАПН України.

Рябова, 3., 2010. Теоретичні аспекти маркетингової діяльності в системі післядипломної освіти. Імідж сучасного педагога, 9(108), с. 9-12.

Соловій, І.П., Геник, Я.В., Соловій, В.І., 2014. Управління професійним навчальним закладом на засадах сталого розвитку: навч.-метод. посібник. Івано-Франківськ: "Лілея-НВ".

Мачей Груза, Пьотр Стронковські, 2018. U-LEAD with Europe Ukraine Local Empowermant, Accountabillity and Developmant Program: Огляд ситуації у сфері професійно-технічної освіти в Україні [Із рекомендаціями щодо можливих покращень]. В: Звіт в рамках Національного проекту "Децентралізація". Київ-Варшава.

\section{Translated \& Transliterated}

Harkusha, N.M., Tsukova O.V., Horoshanska, O.O., 2011. Modeli y metody pryiniattia rishen v analizi ta audyti [Models and methods of decision-making in the analysis and audit]. Kyiv: Znannia. (Vyshcha osvita XXI stolittia), [in Ukrainian].

Svystun, V.I., Aistrakhanova, D.D., Yelnykova, H.V ta in., 2012. Detsentralizatsiia upravlinnia profesiino-tekhnichnoiu osvitoiu: monohrafiia [Decentralization of management of vocational education: monograph.]. Kyiv: Pedahohichna dumka, [in Ukrainian].

Kushnir, I. I., 2013.Zmist marketynhovoi kompetentnosti kerivnykiv vyshchykh navchalnykh zakladiv I-II rivniv akredytatsii. Naukovyi visnyk Uzhhorodskoho universytetu: Seriia: Pedahohika. Sotsialna robota [Scientific herald of Uzhgorod University. Series: Pedagogy. Social work], 27, s. 99-102, [in Ukrainian].

Liepa, Ye.K., Debela, I.M., 2007. Prohnozuvannia sotsialno-ekonomichnykh protsesiv [Forecasting of socio-economic processes]: navch. posib. dlia stud. ekonom. spets. Kherson : VAT "Khersonska miska drukarnia", [in Ukrainian].

Svystun, V.I., Pomaran, P.I., Palkevych, Yu.S., Chernobuk, H.H. ta in., 2015. Marketynhove upravlinnia profesiinotekhnichnym navchalnym zakladom v umovakh rynkovoi ekonomiky [Marketing management of vocational training institution in the market economy]: metod. posib. /za red.V.O.Radkevych, V.I. Svystun. Romny: Romenske VPU, [in Ukrainian].

Anishenko, V.M., Zakatnov, D.O., Zdiruk, S.I. ta in., 2008. Napriamy reformuvannia profesiino-tekhnichnoi osvity v umovakh yevropeiskoi intehratsii (dosvid, analiz, prohnozy) [Directions of reforming vocational education in the conditions of European integration (experience, analysis, forecasts)]: kolektyvna monohrafiia. Kyiv: IPTO NAPN Ukrainy, [in Ukrainian].

Palkevych, Yu.S., 2014. Upravlinnia konkurentospromozhnistiu osvitnikh posluh profesiino-tekhnichnykh navchalnykh zakladiv: metodychni pidkhody do prohnozuvannia ta planuvannia [Managing the competitiveness of educational services of vocational training schools: Methodological approaches to forecasting and planning.]. Naukovyi visnyk Instytutu profesiino-tekhnichnoi osvity NAPN Ukrainy. Profesiina pedahohika [Scientific herald of the Institute of vocational education of the National Academy of Pedagogical Sciences of Ukraine. Professional Pedagogy.], 1(8), s. 28-32, [in Ukrainian].

Palkevych, Yu.S., 2014. Upravlinnia rozvytkom profesiino-tekhnichnoi osvity: ekonomichnyi aspekt [Management of the development of vocational education and training: the economic aspect.]. V: Rynkovi ekonomichni mekhanizmy staloho rozvytku: innovatsiine ta finansove zabezpechennia: materialy mizhnarodnoi naukovo-praktychnoi konferentsii [Market economic mechanisms for sustainable development: Innovative and financial support: materials of the International scientific and practical Conference ] "9-10 travnia 2014 r. NHU, Dnipropetrovsk), s. 197-198, [in Ukrainian].

Radkevych, V. O., 2012. Kompetentnisnyi pidkhid do zabezpechennia yakosti profesiinoi osvity $i$ navchannia [Competence approach to ensuring the quality of vocational education and training.]. V: Naukovo-metodychne zabezpechennia profesiinoi osvity i navchannia [Scientific and methodical provision of vocational education and training]: materialy Vseukr. (zvit.) naukr.-prakt. konf. (23 bereznia 2012 r., m. Kyiv ), Kyiv: In-t prof.-tekhn. osvity NAPN Ukrainy. Vyp. 1, s. 9-15, [in Ukrainian].

Radkevych, V.O., 2016. Teoretychni ta metodychni zasady rozvytku profesiinoi osvity i navchannia: rezultaty, problemy, perspektyvy [Theoretical and methodological principles of the development of vocational education and training: results, problems, perspectives.]. Naukovyi visnyk Instytutu profesiino-tekhnichnoi osvity NAPN Ukrainy. Profesiina pedahohika [Scientific herald of the Institute of vocational education of the National Academy of Pedagogical Sciences of Ukraine. Professional Pedagogy], 11, s. 5-23, [in Ukrainian].

Svystun, V.I., red., Petrenko, L.M., Protsenko, N.D., 2016. Rozvytok marketynhovoi kompetentnosti kerivnykiv PTNZ [Development of marketing competence of the directors of the VET institutions]: nauk.-metod. posib. Kyiv: IPTO NAPN Ukrainy, [in Ukrainian].

Riabova, Z., 2010. Teoretychni aspekty marketynhovoi diialnosti v systemi pisliadyplomnoi osvity [Theoretical aspects of marketing in the system of postgraduate education.]. Imidzh suchasnoho pedahoha [The image of a modern teacher], 9(108), s. 9-12, [in Ukrainian].

Solovii, I.P., Henyk, Ya.V., Solovii, V.I., 2014. Upravlinnia profesiinym navchalnym zakladom na zasadakh staloho rozvytku [Management of vocationall institution on the basis of sustainable development]: navch.-metod. posibnyk. Ivano-Frankivsk: "Lileia-NV", [in Ukrainian].

Machei Hruza, Potr Stronkovski. 2018. U-LEAD with Europe Ukraine Local Empowermant, Accountabillity and Developmant Program: Ohliad sytuatsii u sferi profesiino-tekhnichnoi osvity v Ukraini [A Review of the situation in the sphere of vocational education and training in Ukraine] [Iz rekomendatsiiamy shchodo mozhlyvykh pokrashchen] [Recommendations for possible improvements]., V: Zvit v ramkakh Natsionalnoho proektu "Detsentralizatsiiia" [Report within the framework of the national project "Decentralization"]. Kyiv-Varshava, [in Ukrainian]. 


\section{Маркетингова компетентність керівників у забезпеченні конкурентоздатності закладів професійної (професійно-технічної) освіти на ринку освітніх послуг}

\section{Олена Загіка,}

кандидат педагогічних наук, директор Вищого професійного училища №25 м. Хмельницького,

Реферат. Заклад професійної (професійно-технічної) освіти розглядається як відкрита соціально-педагогічна система, суб'єкт ринкових відносин, що функціонує одночасно на ринку освітніх послуг і ринку праці, забезпечуючи виявлення та задоволення освітніх потреб споживачів через пропозицію освітніх послуг. Доведено, що найкращих результатів розвиток людського капіталу досягає у сприятливому середовищі економічного зростання, де рішення щодо підготовки робітників і фахівців приймаються на основі соціального партнерства на місцевому та регіональному рівнях. У цьому контексті проаналізовано основні ідеї впровадження механізмів моніторингу, кращого регулювання та забезпечення якості професійної освіти, підготовки кадрів відповідно до поточних і перспективних потреб ринку праці в умовах децентралізації, посилення співпраці між публічними адміністраціями та роботодавцями, налагодження соціального партнерства. Особливої актуальності набуває пошук сучасних підходів до планування діяльності закладу освіти, підвищення якості надання освітніх послуг, ефективної підготовки фахівців, зокрема, планування маркетингової діяльності, основною метою якого є підвищення конкурентоспроможності закладів та їх освітніх послуг.

Автором розглянуто маркетинговий підхід до управління конкурентоздатністю закладу освіти на основі вивчення тенденцій розвитку економіки і ринку праці, потреб та інтересів споживачів освітніх послуг, визначено критерії конкурентоздатності закладу освіти. Встановлено, що для забезпечення адаптації освітньої пропозиції до потреб ринку праці, впровадження сучасних інформаційно-аналітичних інструментів ефективного планування і управління закладами професійної (професійно-технічної) освіти, необхідним є створення наукового підгрунтя розвитку маркетингової компетентності їх керівників. Проаналізовано концептуальні засади компетентнісного, системного, адаптивного, інформаційного підходів, які є методологічним підгрунтям визначення змісту та формування системи розвитку маркетингової компетентності керівників, пошуку шляхів підвищення ефективності прийняття управлінських рішень щодо діяльності і розвитку закладів професійної (професійно-технічної) освіти.

Ключові слова: професійно-технічна освіта, конкурентоздатність закладу освіти, маркетингове управління, маркетингова компетентність керівника, ринок освітніх послуг. 